\title{
The Political and Religious Status in Seljukian Anatolia in 1200s
}

\author{
Tunay KARAKÖK \\ Dr. Öğr. Üyesi, Bartın Üniversitesi, Edebiyat Fakültesi, Tarih Bölümü, \\ Bartın, Türkiye, tkarakokl@bartin.edu.tr (Sorumlu Yazar/Corresponding Author)
}

\begin{tabular}{|c|c|}
\hline Article Info & ABSTRACT \\
\hline $\begin{array}{l}\text { Article History } \\
\text { Received: } 23.06 .2021 \\
\text { Accepted: } 09.12 .2021 \\
\text { Published: } 31.12 .2021 \\
\text { Keywords: } \\
\text { XIIIth Century, } \\
\text { Anatolia, } \\
\text { Religious Life, } \\
\text { Political Life, } \\
\text { Seljukians. }\end{array}$ & $\begin{array}{l}\text { Anatolia is a geography that has been subjected to various invasion and conquest movements } \\
\text { throughout history. Surrounded by the continents of Asia, Europe and Africa, Anatolia also acts as } \\
\text { a bridge between Asia and the European continents. This bridge is surrounded by the Old East } \\
\text { worlds such as Mesopotamia and Egypt from the southeast and the Old West worlds formed by the } \\
\text { Mediterranean civilizations from the west. In addition to being a physical bridge to Anatolia, this } \\
\text { feature also imposes the duty of intermediation between cultures and interaction. When the } \\
\text { historical process is examined, it is seen that the Anatolian peninsula has been home to civilizations } \\
\text { in every period of history. For this reason, Anatolia is called the "Cradle of Civilizations". All of } \\
\text { the civilizations understood to have been established in different historical periods in Anatolia are } \\
\text { called "Anatolian Civilizations". Known as Anatolia or Asia Minor, this region dates back to the } \\
\text { XIIIth century. When we look from the window of the century, a different picture emerges both } \\
\text { politically and religiously. }\end{array}$ \\
\hline
\end{tabular}

\section{0’ler Selçuklu Anadolusu'nda Siyasi ve Dini Durum}

\begin{tabular}{|c|c|}
\hline Makale Bilgileri & ÖZ \\
\hline $\begin{array}{l}\text { Anahtar Kelimeler: } \\
\text { XIII. Yüzyıl, } \\
\text { Anadolu, } \\
\text { Dini Hayat, } \\
\text { Siyasi Hayat, } \\
\text { Selçuklular. }\end{array}$ & $\begin{array}{l}\text { Anadolu, tarih boyunca türlü istila ve fetih hareketlerine maruz kalmış bir coğrafyadır. Asya, } \\
\text { Avrupa ve Afrika kıtaları tarafından kuşatılan Anadolu, Asya ile Avrupa kıtaları arasında da bir } \\
\text { köprü vazifesi görür. Bu köprü, güneydoğudan Mezopotamya ve Mısır gibi Eski Doğu, batıdan ise } \\
\text { Akdeniz medeniyetlerinin oluşturduğu Eski Batı dünyaları tarafından çevrilmiştir. Bu özelliği } \\
\text { Anadolu'ya fiziki açıdan köprü olmanın yanında kültürler arası geçiş ve etkileşim aracılığı vazifesi } \\
\text { de yüklemiş olmaktadır. Tarihi süreç incelendiğinde Anadolu yarımadasının kesintisiz olarak } \\
\text { tarihin her döneminde medeniyetlere ev sahipliği yaptı̆̆ı görülmektedir. Bu nedenle Anadolu } \\
\text { "Medeniyetlerin Beşiği" olarak adlandırılmaktadır. Anadolu'da farklı tarihi süreçlerde kurulduğu } \\
\text { anlaşılan medeniyetlerin tamamına "Anadolu Medeniyetleri" denmektedir. Anadolu ya da Küçük } \\
\text { Asya adıyla bilinen bu bölge tarihine XIII. yüzyıl penceresinden baktığımızda ise hem siyasi hem } \\
\text { de dini olarak farklı bir tablo karşımıza çkmaktadır. }\end{array}$ \\
\hline
\end{tabular}

Atıf/Citation: Karakök, Tunay. "The Political and Religious Status in Seljukian Anatolia in 1200s". Selçuklu Medeniyeti Araştırmaları Dergisi (SEMA) 6 (Aralık 2021), 44-54. https://doi.org/10.47702/sema.2021.14 


\section{INTRODUCTION}

The conquest of the Anatolian geography, which has been invaded by different states many times throughout history or has been organized for conquest purposes, is an important issue. As a result; it is possible to come across with more stories or narratives in the works written by historians on this geography. From this point to the move, the XIIIth century which is the time period examined in this study, the political and religious situation of Anatolia is also important. The political structure of Anatolia in the XIIIth century was mixed. There is no solid state authority. The country was plundered, burned and destroyed by the Mongol raids. There was no security left in the city or the village. Property was seized by force, dying or living was found by chance. This unrest caused people to favor sufism, who preached to pull from the world and opened the doors of a brilliant divine realm. People whose lives were unsecured sought peace in the spiritual atmosphere of the order or under the influence of some sheikhs. As for the social and economic structure of Anatolia, a magnificent development has been made. A complete social peace order was established. Anatolia became a center where the christian world and the islamic world were intertwined. The devotion and loyalty of the christian people to the muslim Turkish rulers gradually increased. It reached its peak during this period. Complete freedom of conscience and belief throughout the country, it took place and human will was highly valued. The situation in the economy was also at a bright point in parallel. Anatolia was almost a world trade center. The country was enriched by trade and agriculture. Revenues were at their peak according to the age. Cities such as Konya, Sivas and Erzurum had overflowed the walls around them. The population of Sivas was around 120,000. However, the easy victory of the Mongolian army in Kösedağ in $1243^{1}$ destroyed the authority of the Anatolian Seljuk State, which was the dominant power in Anatolia at the time, and Anatolia was turned into a hell of plunder, plunder and chaos. Mongolian pressure, which gradually settled in Anatolia. Turkish people away from the prosperous life they lived in. The initial brutal repression of the Mongols paralyzed the entire administrative mechanism. The Mongol invasion in Anatolia was a crisis in all its aspects, even Anatolia, it turned into a disaster in terms of his Turkishness. Cultural mines in Anatolia such as Konya, Kayseri, Sivas, Erzurum, Erzincan and Aksaray took their share from the looting and robberies during the invasion. Although the deteriorating political authority was attempted to be reestablished either individually or through alliances by the Anatolian Principalities, which made great contributions to the Turkification and Islamization of Anatolia. Unfortunately, it could not be realized until the Ottoman Empire was established at the beginning of the XIVth century. ${ }^{2}$

\footnotetext{
${ }^{1}$ In 1243, the Mongolian army and the Seljuk army met in Kösedağ. Sultan Giyaseddin Keyhüsrev, who was at the head of the Anatolian Seljuk army, left the battlefield without fighting with the Mongols. As a result, the Mongols, who gained an easy victory, started to invade Anatolia (Hakk1 Dursun Y1ldız, Doğuştan Günümüze Büyük İslâm Tarihi, VII: Selçuklular (İstanbul: Çă̆ Yayınları, 1989), 305.

${ }^{2}$ Osman Turan, Selçuklular Zamanında Türkiye (İstanbul: 1971), 389-402; Osman Turan, Selçuklular Tarihi ve Türk İslâm Medeniyeti (İstanbul: 1993), 361-374; Osman Turan, Selçuklular ve İslâmiyet (İstanbul: 1980), 161-170; Faruk Sümer, “Anadolu'da Moğollar”, Selçuklu Araştırmaları Dergisi, I (Ankara: 1969) 1-47; Kerimüddin Mahmud Aksarayi, Müsameretü'l-Ahbar, çev. Mürsel Öztürk (Ankara: 1943), 305-308; Anonim Selçukname, nşr. F. Nafiz Uzluk (Ankara: 1952), 83-84.
} 


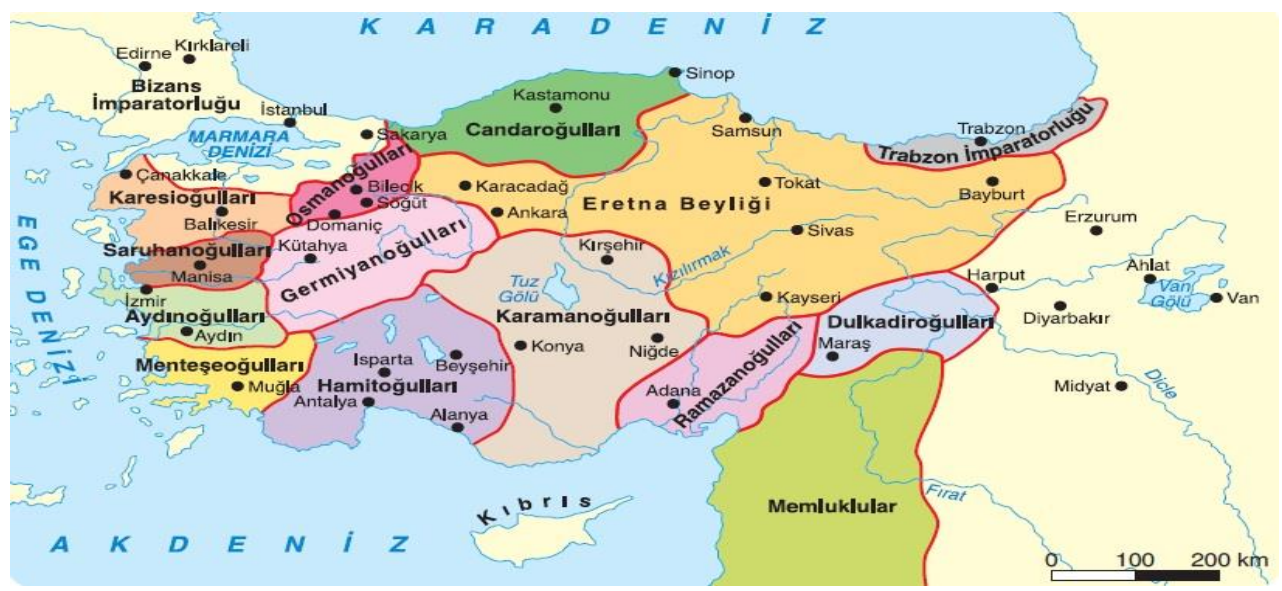

Photo 1. Anatolia in XIII-XIVth centuries ${ }^{3}$

The sources used in this study were subjected to descriptive analysis in order to reach the required information and the findings obtained were reflected in the study. The importance and originality of this work, which is aimed to be completed from piece to whole, is the political and religious life in Anatolia in the XIIIth century can be explained with examples and evidence. It can be expressed as contributing. First of all, a field study, literature review, determination and classification of the sources containing information about the political and religious fields of the period to be examined, finding the information in modern works found to be relevant to the subject and blending them with the previous ones were accepted as the method of the study.

\section{1-Political Situation in Anatolia in the XIIIth Century}

Without mentioning the conquest of Anatolia by the Turks, it is a difficult issue to understand the political structure of Anatolia in the XIIIth century. So much so that the Turks, who were at the top of the founding elements of the effective political structures of the period, which constituted the time period of this study, started to come to the Anatolian geography intensely and in masses with the conquest movements they started after in 1071 wirh the Mangizert and started to settle immediately by owning the places they came from. At this point; in the Anatolian geography, first of all, the struggles with Byzantium continued increasingly, especially the Armenian, Georgian and Greek elements, who were the dominant elements of the places they came from. The conquest understanding of the Turks after the great Miryokefalon victory in 1176 has undergone a radical change. With this victory, the Turks will want to make Anatolia a Turkish homeland for them and they have not avoided any military, political, economic and religious struggle for this cause. ${ }^{4}$ When looking at the political picture in Anatolia in the XIIIth century, it is necessary to know that there was a Turkish and Byzantine dominance in Anatolia in this century. Because the Byzantine Empire, which was the dominant power in this geography until the end of the 1000s, has now lost this qualification, and we encounter the existence of the Seljuk Turks and the states or principalities they established in this

\footnotetext{
${ }^{3}$ Giresun Gazetesi, (Erişim Aralık 2020).

${ }^{4}$ Turan, Selçuklular Zamanında Türkiye, 221; Turan, Selçuklular ve İslâmiyet, 259; Mükrimin Halil Yinanç, “Anadolu'nun Fethi”, Türkler, VI (Ankara: Yeni Türkiye Yayınları, 2002), 194; Mustafa Kafalı, “Anadolu’nun Fethi ve Türkleşmesi”, Türkler, VI (Ankara: Yeni Türkiye Yayınları, 2002),177-202).
} 
geography. Especially after the Miryokefalon victory in 1176, the Turkish presence in Anatolia gained certainty and the Turks started to dominate Anatolia. ${ }^{5}$

In total between the years 1096-1272 by Pope Urbanus II will be commemorated with the Crusades name consisting of eight time expeditions in Byzantine initial plan with the sequence Turkey has managed to undo the whole Western Anatolian coast with the Seljuk capital of Nicaea, and even Crusaders located in Anatolia in Antakya, a county, together with a county each in Urfa and Tripoli, they succeeded in establishing a kingdom in Jerusalem, which was the main target. ${ }^{6}$ All these things show that with the beginning of the XIIth century, the Anatolian geography was subjected to Crusader attacks and as a result of this situation, Anatolia was occupied, burned down and destroyed, turning into a geography where both population and economic decline was experienced. As a result of these campaigns that started in 1096 and lasted until the 1270s, the Anatolian political arena with the Urfa and Antakya Crusader Counties and the Anatolian political arena faced new figures, while the Byzantine Empire, whose authority was reduced and limited only to the Marmara beaches, returned to its glorious days. It has succeeded in fueling their hopes of return. Last century in Anatolia, the Byzantine Empire period began to regain its former power, especially the Turkish-Islamic forces across Seljuk State and Danişmends ment from early principalities, Artuk and knock the principality for the the period they begin to end the political variyet has been experienced. ${ }^{7}$

As the end of the XIIth century approaches, the Anatolian Seljuk State in Anatolia, Kılıç Arslan II (1155-1192) divided the state among his sons before his long reign ended. Therefore, although there was a disintegration that did not last long after him, his son II. Süleymanşah (11961204) restored the union. After Keyhüsrev I (1205-1211) and İzzeddin Keykavus (1211-1220) 's ruling in Anatolia, Seljuks experienced a more stable period, and the state has soared from every angle. During the time of Alaeddin Keykubad I (1220-1237), this rise continued and a period of full maturity was experienced in every aspect. However, during the reign of Sultan Keykubad, he will have to face the second great disaster after the Anatolian; tha was Mongolian invasion. Because the Mongol Khan Genghis Khan and his armies were flocking to the west from Central Asia like a flood. The Sultan, on the other hand, was calculating not to fall into the strategy mistakes his ancestors had fallen into during the Crusades, and to protect the Anatolian Turkish political unity, which was recently established to a great extent. For this reason, he established a political alliance with the Eyyubis, another Muslim state of the period and who was influential in Egypt - Damascus geographies, through kinship, and managed to dominate the sides of Diyarbakır and Erzurum. In this way, the Mengüceks principality, which was the effective element of these regions, ended and finally succeeded in establishing the Anatolian Turkish unity, which was completed before it. ${ }^{8}$

\footnotetext{
5 Coşkun Alptekin, “Türkiye Selçukluları”, Doğuştan Günümüze Büyük İslam Tarihi, VIII, Ed. Kenan Seyithanoğlu (İstanbul: 1989), 209-406; Ali Sevim, Anadolu'nun Fethi: Selçuklular Dönemi (Ankara: 1993), 18-32.

${ }^{66}$ Zoé Oldenbourg, The Crusades (New York: 1966), 53-77; Louis Bréhier, The Life And Death Of Byzantium, Çev. Margaret Vaughan (Amsterdam: 1977), 206; Peter Charanis, The Byzantine Empire In The Eleventh Century, A History Of The Crusades, I (Madison: 1969), 177-219; Anna Komnena, Alexiad, Çev. Bilge Umar (İstanbul: 1996), 157-160; Jonathan Harris, Byzantium And Crusades (New York: 2003), 53-54; Steve Runciman, Haçlı Seferleri Tarihi I, (Ankara: 1986), 56-58.

${ }^{77}$ Işın Demirkent, Haçlı Seferleri (İstanbul: 1997), 56-57; Amin Maalouf, Arapların Gözünden Haçlı Seferleri, Çev. Ali Berktay (İstanbul: 2012), 121-126; Steve Runciman, Haçlı Seferleri Tarihi I, 87-88; Turan, Selçuklular ve Islâmiyet, 42.

${ }^{8}$ Ali Sevim, Erdoğan Merçil, Selçuklu Devletleri Tarihi Siyaset, Teşkilat ve Kültür (Ankara: 2014), 435-441, 459, 467; Rıza Nur, Türk Tarihî, III (İstanbul: 1979), 76-78; İbrahim Kafesoğlu, Selçuklu Tarihi (İstanbul: 1992), 40, 59, 61, 63 .
} 
Ascended to the throne after Keykubad II, Keyhüsrev witnessed the great migration waves caused by the Mongols during this period. As a result of this immigration wave that started in the 1220s, a large part of the Turks from Transoxiana, Iran and Azerbaijan, a part dominated by nomadic elements, had to migrate to Anatolia. In the end of the day these migrations in Anatolia as a result of economic, social, cultural and religious life will undergo major changes, but this process is more Turkey works for the Seljuk State has taken a case. The newcomer population has a high military qualification, making the state strong in terms of the number of soldiers. Thanks to this situation, even the Mongol army, which invaded Georgia in 1240 and reached the Seljuk border, would not dare to cross the Seljuk border. However, at this time, an anti-government rebellion with a religious character, called the "Babai revolt", which would be most beneficial for the Mongols and weaken the Seljuks against the Mongols, would emerge ${ }^{9}$ In 1240, Turkmens first revolted in Adiyaman - Kefersud and seized this place, and with the participation of some non-Muslim groups in the uprising in a short time, the revolt spread to central Anatolia in a short time. However, before a long time passed, Baba Ilyas, who was seen as the leader of the rebellion due to the measures taken by the Seljuk administration, was captured and executed by the Seljuk forces in Amasya. This event worsened the situation and Baba Ishak, who wanted to avenge him, came to Amasya with a large force and marched on Konya. However, he was defeated and killed by the Seljuk army near Kırşehir. Most of the Turkmens were slaughtered; the rest were captured; Those who survived the caliphs managed to escape left and right and lose their tracks. This rebellion, which is frequently mentioned in the sources that it was caused by social and economic problems rather than religious issues, which reveal the weakness of the Seljuk State, could hardly be suppressed after heavy losses were inflicted by the Seljuk troops. As a result of this incident, which reveals the inability of the state, a significant part of the Seljuk armies, which had been prepared for the Mongols who had previously reached the borders, will be assigned to suppress the rebellion and most of it will be lost. ${ }^{10}$ In the Kösedağ War (1243) with the Mongols, the state, which was weak and had insufficient number of soldiers, would not be able to avoid being defeated, and the state, representing nearly two and a half centuries of Anatolian Turkish unity, Turkish power and Turkish civilization, lost its influence from Anatolian politics and became a state subject to the Mongols. This situation caused the political unity in the country to break down, the rulers who ascended to the Seljuk throne to be crushed under the Mongol domination, and Anatolia to a complete chaos. $^{11}$

As a manifestation of this fragmentation, Ottomans (1299--1922), Hamidids (1301--1423), Karesioğulları (1304--1360), Candarids (1292--1461), Menteşeoğulları (1261-- 1424), Aydınoğulları (1261--1424), 1308-1426), Karamanids (1250-1487), Dulkadiroğulları (1337-1515), Germiyanoğulları (1299-1429), Ramazanoğulları (1353-1608) and Saruhanoğulları (1313-1410), more than twenty Turkmen principalities were established and each was created by the Mongols to fill the authority gap

\footnotetext{
${ }^{9}$ Ali Sevim - Erdoğan Merçil, Selçuklu Devletleri Tarihi Siyaset, Teşkilat ve Kültür, 297-298; Çağatay Uluçay, Illk Müslüman Türk Devletleri Tarihi (İstanbul: 1977), 250; Ali Sevim - Yaşar Yücel, Türkiye Tarihi: Fetihten Osmanliya Kadar, I (Ankara, 1995), 228-230; Ahmet Yaşar Ocak, Babailer İsyanı (Aleviliğin Tarihsel Altyapısı Yahut Anadolu'da İslam-Türk Heterodoksisinin Teşekkülü (Ankara: 2016), 21-23; Ahmet Yaşar Ocak, Babâîler İsyânı ve Bektâşîlik (İstanbul: 2014), 49.

${ }^{10}$ Ahmet Yaşar Ocak, Bektaşi Menakıbnâmelerinde İslâm Öncesi İnanç Motifleri (İstanbul: 1983), 1, 17, 70, 114, 147-148; Turan, Selçuklular Tarihi ve Türk İslâm Medeniyeti, 34, 296, 300, 353; Yusuf Ayönü, Selçuklular ve Bizans (Ankara: 2014), 174.

${ }^{11}$ Kemal Taşcı, Kösedağ Savaşı Öncesi Moğolların Doğu Anadolu'daki Siyasi ve Askeri Faaliyetleri (Sivas: 2018), 165-171; Fatma Çapan, Kösedağ Savaşına Giden Yolda Türkiye Selçuklu Devletinde İ̧ Siyasi Durum (Sivas: 2018), 202-204; Erkan Göksu, Kösedăg Savaşı ve Türkiye Selçuklu Ordusu (Sivas: 2018), 258-259; Ahmet Kütük, Kösedağ Savaşının Kaybedilmesinde II. Glyaseddin Keyhüsrev'in Kişiliği ve Uygulamalarının Rolü (Sivas: 2018), 297-302.
} 
with each other, which is sometimes weak and sometimes in Anatolia in the position of vassal states (Turkey) they have even had to contend with in alliance with the Seljuk Sultan of Mongols. ${ }^{12}$ Looking at the recent history books; The period in which these principalities took place is called the second principality period, and there is not much information about Anatolia in this period due to lack of resources. So much so that the written sources of this period contain information about the principalities established in Western Anatolia. ${ }^{13}$ It is known that this information is about general geographical depictions, country and city depictions. According to the sources obtained this period; starting from the 1240s, when the Mongols ended the Seljuk reign and the disbanded princes took shelter in these principalities, it continued until Sultan Yavuz Sultan Selim invaded the Ramazanoğulları principality in 1517 for the Ottoman Empire. ${ }^{14}$

These principalities, which came out of the Seljuk debris, are named by some historians as Tavaif-i Mülukk or nation rulers. These principalities, which generally adopted the high Seljuk culture, lived and lived this culture in depth that they spoke Turkish in Anatolian lands, made Turkish the official language in Anatolia for the first time, and by translating important books written in Arabic and Persian into Turkish, their Turkish identity was at the forefront at every opportunity. They tried to take it out. These principalities, which have very strong presence, are often independent states, recognizing the Seljuk authority, accepting the Mongol supremacy. Although Karamanids came to the fore among the principalities in terms of ensuring the political unity of Anatolia after the Seljuks, towards the end of the century, the Ottomans were much closer to this goal. The Ottomans were in the Anatolian identity during this period and joined the Ottoman rule, which would later manage to gather themselves under a single roof, almost without any change. ${ }^{15}$ In 1255 his elder brother Meng by Khan in the Middle East Mongols conquered yet is appointed to complete the conquest of the incomplete land Hulagu Khan, established the Ilkhanid to the center of Tabriz in 1256 and thus in 1243 with Kösedağ war Anatolia taken under clout after the war (Turkey) Seljuk State and Mongol pressure on its territory has become more systematic. After a short while, during the Battle of Aynicâut War in 1260, the Muslim Turkish state, the Mamluks, who ruled in Egypt, Syria and the Hijaz in 1250-1517, defeated the Ilkhanids of Hülâgû Khan under the leadership of their ruler Sultan Baybars (1260-1277), and after a while they started to expand their domains of sovereignty towards Anatolia by taking over. So much so that the first work done in accordance with this purpose was the abolition of the Crusader County of Antakya by Baybars and thus, heavy blows were inflicted on the Armenian rule in Çukurova. ${ }^{16}$ Although Karamanids came to the fore among the principalities in terms of ensuring the political unity of Anatolia after the Seljuks, towards the end of the XIVth century, the Ottomans were much closer to this goal. Because the Ottomans captured the lands of most of the Anatolian principalities in this period. In addition, the Ottomans with their transition to Rumelia in the middle of the century, Byzantium, which is still their biggest rival in Anatolia, has become a city-state almost

\footnotetext{
${ }^{12}$ M. Fuad Köprülü, “Anadolu Beylikleri Tarihine Ait Notlar”, Tarih Mecmuast, II (İstanbul: 1928), 22-32; M. Fuad Köprülü, “Anadolu Selçuklu Tarihi’nin Yerli Kaynakları”, Belleten, VII/27 (1943), 379-522384; M. Fuad Köprülü, Anadolu'da Íslamiyet (Ankara: 2005), 29.

${ }^{13}$ M. Feridun Emecen, Ilk Osmanlılar ve Batı Anadolu Beylikler Dünyası (İstanbul: 2001), 86-88; M. Fuad Köprülü, Osmanlı Devleti 'nin Kuruluşu (Ankara: 1984), 35

${ }^{14}$ Faruk Sümer, "Ramazanoğulları", Türkiye Diyanet Vakfi İslâm Ansiklopedisi (İstanbul: TDV Yayınları, 2007), 34/442-447; Yılmaz Kurt, "Ramazanoğulları Beyliği”, Türkler, VI (Ankara: 2002), 816-823; Ahmet Avanas, “Osmanlı Hâkimiyetinde Ramazanoğulları Beyliği”, Selçuk Üniversitesi Eğitim Fakültesi Dergisi, 4 (Konya: 1990), 84-85.

${ }^{15}$ Emecen, Ilk Osmanlılar ve Batı Anadolu Beylikler Dünyası, 86-88; Baron Joseph Van Purgstall Hammer, Büyük Osmanlı Tarihi, I (İstanbul: 1989), 58-59; M. Fuad Köprülü, Osmanlı Devleti’nin Kuruluşu (Ankara: 1984), 35.

${ }^{16}$ Erdoğan Merçil, Müslüman Türk Devletleri Tarihi (İstanbul: 1985), 297-298, Uluçay, İlk Müslüman Türk Devletleri Tarihi, 250; Sevim-Yücel, Türkiye Tarihi: Fetihten Osmanllya Kadar, 228-230.
} 
limited to Istanbul and its surroundings. Already in the last quarter of the XIIIth century, the establishment of direct Mongol administration in Anatolia (1277) in response to Turkey and thoroughly weakened as a result of the Seljuk State authorities, Turkmen lords one began to declare their independence, the cause of the wave of immigration occurred in this century The population density he was in paved the way for new conquests and Byzantium, which was affected most by this situation, was forced to withdraw from the Western Anatolian coasts in a short time. ${ }^{17}$

\section{2-Religious Situation in Anatolia in the XIIIth Century}

Among the nomadic Turks, the most supporters will be the sufism movement Yasawiyya or Yeseviye and a member of the heart named Hodja Ahmet Yesevi, the founder of this movement. A student of Yusuf al-Hemedani, a Sunni Dynasty scholar and mutasavvf, this zat is a person who has studied a strong madrasa education and learned the vision with religious knowledge. Yesevi, who had the ability to express his faith to those around him in a language they could understand and synthesize and make sense of sharia and sufism, soon became a reputation among Turks and managed to affect the cult, which is the systemic form of his views and thoughts, which he called Yasawiyya or Yeseviye spread rapidly among Turks and settled and other cults that emerged afterwards. He is a simple member of the principles of the Islamic religion, sharia and the principles of the Yasawiyya or Yeseviye order he founded. ${ }^{18}$ These sufistic personalities, known by names such as "Horasan Dervishes" and "Colonizer Turkish Dervishes", are especially the potentials we call "extremes" in order to both develop and consolidate the religious consciousness of newly converted Turks and to keep the spirit of ghaza-jihad alive. They concentrated on the fields of jihad. Because these areas were both the settlement areas of Turkmens who recently arrived in Anatolia and the regions close to the Byzantine borders, they were potential jihad or ghaza areas. Dervishes were at the forefront of the nameless heroes who were the spiritual power source of the army by being at the forefront of wars or campaigns that took place in such regions. ${ }^{19}$

These spiritual leaders, who were the architects of both the Islamization and the Turkification process of Anatolia, made new conquests together with the armies, at the same time settled in empty or existing settlements in the new conquest stages and called the villages or places of worship to the places they deemed appropriate. By creating their lodges or mosques, they did not hesitate to deal with whatever the necessities of daily life (agriculture, animal husbandry, trade, politics, military service, etc.) in these places they settled. In other words, while the state both achieved new stages of conquest, it enabled the Turkification, Islamization and the process of participating in the political, economic, socio-cultural and religious life of the state as much as possible. They established their lodges on empty lands in order to gradually organize their places as a village, a center of culture and sect. ${ }^{20}$ Looking at the religious environment that these sufistic personalities who came to Anatolia and clearly expressed in the sources that they played an important and undeniable role in both the conquest and Islamization of Anatolia, when they came to Anatolia; it is seen that the environment is gradually

\footnotetext{
${ }_{17}^{17}$ M. Murat Baskıcı, Bizans Döneminde Anadolu: Iktisadi ve Sosyal Yapı (900-1261) (Ankara: 2009), $24-29$.

${ }^{18}$ Necdet Tosun, "Yeseviyye", Türkiye Diyanet Vakfi İslâm Ansiklopedisi (İstanbul: TDV Yayınlar1, 2013), 43/488-489; Mertol Tulum, "Hikmetlere Göre Yesevîlik ve Orta Asya Kültür Tarihi Bakımından Önemi”, İlmî Araştırmalar, 7 (Ankara: 1999), 208; M. Fuad Köprülü, Türk Edebiyatında İlk Mutasavvıflar (İstanbul: 1976), 38.

${ }^{19}$ Köprülü, Türk Edebiyatında Illk Mutasavvıflar, 49-50; Ömer Lütfi Barkan, "İstila Devrinin Kolonizatör Türk Dervişleri”, Vakıflar Dergisi, II (Ankara: 1974), 295; Ahmet Yaşar Ocak, "Selçuklu ve Beylikler Devrinde Düşünce", Türkler, VII (Ankara: 2002), 425-426.

20 Barkan, "İstila Devrinin Kolonizatör Türk Dervişleri”, 295-296; Köprülü, Türk Edebiyatında İlk Mutasavvıflar, 54; Mehmet Demirci, "Müslüman Türklerde Tasavvuf”, Türkler, V (Ankara: 2002), 489-497.
} 
beginning to coexist with Islam and this situation is now largely completed with the rise of the Ottoman Empire. ${ }^{21}$

The sultans of the Anatolian Seljuk State, the political power that dominated Anatolia in the XIIIth century, gave a great respect and affection to these coming sheikhs and dervishes, and they built dervish lodges in the newly conquered regions and allocated rich foundations to them, just like the sultans of the Turkish-Islamic states before them. If we look at some of these people who were influential especially in the ancient cities of the Anatolian geography and their surroundings; the great Sufi Muhyiddin ibn Arabi, who made the understanding of "Vahdeti Vûcut" which means "... that everything in the universe is a manifestation of God, the only creator, and that all beings are in reality nothing”. Such as Ibn al- Arabī, Awḥad-al-dīn Kermānī in Konya, Fahreddîn-i Irâk in Tokat, Akhī Ewrān and Mawlânâ Djalâl al-Din al-Rumî are first sufistic personalities whose names are to be counted. When we look at the people who are active outside the cities, especially in the provinces where nomadic communities live; Baba Ilyas, Haji Bektash Wali, Sarı Saltuk, Barak Baba, Yunus Emre, Kumral Abdal, Abdal Musa, Geyikli Baba names are mentioned. ${ }^{22}$

In addition to the activities of Sufi masters, there is such a social organization that left its mark on the religious status of Anatolian geography in the said centuries and whose efforts in spreading Islam among the Turks cannot be denied that in fact, it was established as a continuation of the "Futuwwa" organization and was a typical artisan organization. On the other hand, it is the "Ahi Organization", which has been transformed into a religious organization with the lodges and dervish lodges that it founded or supported. Ahi Organization, which was the most widespread and effective Sufi organization among Turks, especially in the XIIIth century; During the period of Kaykhusraw I (1205 - 1211), the son-in-law of Awhad-al-dīn Kermānī, who was known to come from Konya, and Sheikh Nasıreddîn Mahmud b. Ahmed el-Hoyi (d. 1261), the organization served as a bridge between the city dwellers and the nomads, and by combining the religious lives of these two groups, which are an important part of the socio-cultural life, on a common ground, organizations. ${ }^{23}$

\footnotetext{
${ }^{21}$ Ahmet Yaşar Ocak, "Barak Baba", Türkiye Diyanet Vakfi İslâm Ansiklopedisi (İstanbul: TDV Yayınları, 1992), 5/56-57; Ahmet Yaşar Ocak, Osmanlı İmparatorluğunda Marjinal Sûfîlik: Kalenderîler (Ankara: 1992), 71; Resul Ay, Anadolu'da Derviş ve Toplum (13-15. Yüzylllar) (İstanbul: 2008), 12-13.

${ }^{22}$ Ekrem Demirli, "Vahdet-i Vücûd", Türkiye Diyanet Vakfi İslâm Ansiklopedisi (İstanbul, TDV Yayınları, 2012), 42/431; Ekrem Demirli, İslam Metafiziğinde Tanrı ve İnsan: İbnü’l-Arabî ve Vahdet-i Vücûd Geleneği (İstanbul: 2009), 62; Nihat Azamat, "Evhadüddîn-i Kirmân̂”,, Türkiye Diyanet Vakfi İslâm Ansiklopedisi (İstanbul, TDV Yayınları, 1995), 11/518; Orhan Bilgin, "Fahreddîn-i Irâk $\overrightarrow{1} "$, Türkiye Diyanet Vakfi İslâm Ansiklopedisi (İstanbul, TDV Yay., 1995), 12/84-86; Ocak, Osmanlı İmparatorluğunda Marjinal Sûfilik: Kalenderîler, 61, 82-85; İlhan Şahin, "Ahî Evran", Türkiye Diyanet Vakfi İslâm Ansiklopedisi (İstanbul, TDV Yayınları, 1988), 1/529; Reşat Öngören, "Mevlânâ Celâleddîn-i Rûmî", Türkiye Diyanet Vakfi İslâm Ansiklopedisi (İstanbul, TDV Yayınları, 2004), 29/441; Ocak, Selçuklu ve Beylikler Devrinde Düşünce, 431432; Ocak, "Baba Illyas", 368; Ahmet Yaşar Ocak, "Geyikli Baba", Türkiye Diyanet Vakfi İslâm Ansiklopedisi (İstanbul, TDV Yayınları, 1996), 24/45; Machiel Kheil, "Sarı Saltuk", Türkiye Diyanet Vakfi İslâm Ansiklopedisi (İstanbul, TDV Yayınları, 2009), 36/147-150; Ocak, Babailer İsyanı, 27; Mustafa Tatc1, "Yunus Emre", Türkiye Diyanet Vakfi İslâm Ansiklopedisi (İstanbul, TDV Yayınları, 2013), 43/600; Orhan F. Köprülü, "Abdal Kumral”, Türkiye Diyanet Vakfi İslâm Ansiklopedisi (İstanbul, TDV Yayınları, 1988), 1/63; Abdurrahman Güzel, Kaygusuz Abdal (Ankara: 1981), 29; Ahmet Yaşar Ocak, "Hac1 Bektâş-1 Velî", Türkiye Diyanet Vakfi İslâm Ansiklopedisi (İstanbul, TDV Yayınları, 1996), 14/455-456; Resul Ay, Anadolu'da Derviş ve Toplum (13-15. Yüzyllar), 16-17.

${ }^{23}$ M. Saffet Sarıkaya, "Türklerin İslamlaşma Süresince Mezheplerin ve Tarikatların Yeri”, Türkler, V (Ankara: 2002), 505; Murat Bardakçı, "Türklerin Sosyal ve Kültürel Hayatında Tasavvuf ve Tarikatlerin Yeri”, Türkler, VII (Ankara: 2002), 452; Hasan Basri Öcalan, "Anadolu Selçukluları Zamanında Tasavvufî Düşünce", Türkler, VII (Ankara: 2002), 466-467; Abdülbaki Gölpınarlı, İslam ve Türk Illlerinde Fütüvvet Teşkilatı (İstanbul: 2011), 48-51; Franz Taeschner, "İslâm Ortaçağında Futuvva (Fütüvvet Teşkilatı)", çev. Fikret Işıltan, İstanbul Üniversitesi Illahiyat Fakültesi Mecmuası (IFM), XV (İstanbul, 1953), 6.
} 
In the XIIIth century, Anatolian Seljuks continued the tradition of valuing these personalities like the Great Seljuks. In fact, the sultans of the Anatolian Seljuks opened the doors of their palaces, especially to the sheikhs within this group, and adopted it as a principle to show respect to them in every field and in every sense. Thanks to their positive and even protective attitudes, these personalities have enabled them to put forward their own Sufi knowledge in the Anatolian area. Thus, they placed the Sufism movement and the concept of Sufism in Anatolia. Ibn al- Arabī, Awhad-al-dīn Kermānī, Akhī Ewrān, Mawlânâ Djalâl al-Din al-Rumî, Haji Bektash Wali, Fahreddîn-i Irâk, Yunus Emre and Baha al-din Mohammad Walad who brought important names led to the formation of religious orders in Anatolia. In this context, the first striking sect was the Yeseviye. However, it would be wrong to attribute the entire formation of Sufism and culture existing in Anatolia to this sect. So much so that in this period in Anatolia; sect formations such as Rifa 'iyya, Kubrawiyya, Qadiriyya, Qalandariyyah Naqshbandiyah, Bektashiyah and Mawlawiyya sects are observed. As a result of this situation, there was a great mystical movement in Anatolia in the XIIIth century. ${ }^{24}$ These personalities, who are extremely influential among the people, at the same time; sometimes they did not hesitate to broadcast their founders or their sects, teach in madrasahs, give sermons in mosques and create conversation rings, and create new settlements with their supporters. In addition to all these, social communities with a mystical aspect were also established in this process. In the Âşıkpaşazâde, the four groups given as "Ahiyân-ı Rûm", "Gâziyân-ı Rûm", "Abdalân-ı Rûm" and "Bacıyân-ı Rum". They have been very influential in the religious and social life of Anatolia in this century. Sheikhs were appointed by the state for the dervish lodges and lodges, which belonged to these groups and served as means of settlement and colonization, and as a result, the institution of dervish lodges and zawiya emerged in Anatolia. Now, the duty of sheikhdom in state administration has become a civil service. Having a non-Muslim population structure with Muslims and Christians, especially Orthodox Christians, Anatolia had a completely tolerant climate in this period. In this climate, he found the opportunity to live in religious elements that perpetuate the Jewish, Zoroastrian and even Central Asian belief system. ${ }^{25}$

\section{CONCLUSION}

As a result; XIII. until the end of the century; XI. At the beginning of the century until the Kösedağ War that took place in 1243, Anatolia (Turkey) Seljuk Empire and the money that I Principalities period, wherever it occurs in a process called Anatolia; While trying to build a new home for the Turks with the Great Seljuk State centered raids, XII. century in Anatolia (Turkey), the Seljuk State sovereignty in its contribution to the principality established in Central and Eastern Anatolia, the Crusades scene was Catholic Christian struggle against the world with the papacy and the Byzantine Empire under the name. In this geography, where the process of becoming a Turkish homeland accelerated with two important Turkish victories in 1071 and 1176, XIII. With the Mongol invasion in the second quarter of the century, II. The Period of Principalities has started. The period in question will end with the termination of the political existence of the political organization established in Southeastern Anatolia under the name of the Ramazanoğulları Principality during the Egyptian Expedition made by this state in 1517, after the Osmanoğulları Principality, which was established in this period, became the Ottoman State. In other words, XIII. Anatolia, whose political

\footnotetext{
${ }^{24}$ Resul Ay, Anadolu'da Derviş ve Toplum (13-15. Yüzylllar) (İstanbul: 2008), 19-21; Sarıkaya, "Türklerin İslamlaşma Süresince Mezheplerin ve Tarikatların Yeri”, 506-508; Öcalan, “Anadolu Selçukluları Zamanında Tasavvufi Düşünce”, 467-469.

${ }^{25}$ Bardakç1, "Türklerin Sosyal ve Kültürel Hayatında Tasavvuf ve Tarikatlerin Yeri”, 457-459; Öcalan, "Anadolu Selçukluları Zamanında Tasavvufî Düşünce”, 473; Ocak, Osmanlı Imparatorluğunda Marjinal Sûfîlik: Kalenderîler, 59-62; Ay, Anadolu'da Derviş ve Toplum (13-15. Yüzyıllar), 26-29; Aş1kpaşazâde, Âşıkpaşazâde Tarihi: Tevârih-i Âli Osman, nşr. Âli Beğ, çev. Necdet Öztürk (İstanbul: 2017), 205.
} 
appearance was colorful in the century; In this century, a geography that witnessed the Turkish-Islamic conquests and settlements and largely the military, political, economic, religious and socio-cultural activities of the Turks presents an image.

It is a fact that one of the most important events of both Turkish and Islamic history is undoubtedly the Islamization of Anatolia. Turkmens who came to Anatolia are not only nomads or city dwellers, but also sufi, dervish, saint, chaelebi, sheikh, murid etc. There were also personalities mentioned by names. However, the migration of the members of this group to Anatolia occurred mostly during the Mongol invasion years. Because in this period, Turkistan, Transoxiana and Khorasan regions were at the top of the regions invaded by the Mongols, and these regions were the center of mystical life in this period. The invasion of these places, which contain a dense Sufi mass, caused these personalities to flock from here to Anatolia.

Funding / Finansman: This research received no external funding. / Bu araştırma herhangi bir dış fon almamıştır.

Conflicts of Interest / Çıkar Çatışması: The author declare no conflict of interest. / Yazar, herhangi bir çıkar çatışması olmadığını beyan eder.

\section{REFERENCES}

Aksarayi, Kerimüddin Mahmud. Müsameretü'l-Ahbar. çev. Mürsel Öztürk, Ankara: 1943.

Alptekin, Coşkun. "Türkiye Selçukluları", Doğuştan Günümüze Büyük İslam Tarihi, VIII, Ed. Kenan Seyithanoğlu, VIII, 209-406, İstanbul: 1989.

Anonim. Selçukname, nşr. F. Nafiz Uzluk, Ankara: 1952.

Anonim. Doğuştan Günümüze Büyük İslam Tarihi, VIII, 305-306, İstanbul: 1989.

Aşıkpaşazâde. Âşıkpaşazâde Tarihi: Tevârih-i Âli Osman. nşr. Âli Beğ, Trc. Necdet Öztürk, İstanbul, 2017.

Avanas, Ahmet. "Osmanlı Hâkimiyetinde Ramazanoğulları Beyliği”. Selçuk Üniversitesi Eğitim Fakültesi Dergisi 4 (1980), 81-88.

Ay, Resul. Anadolu'da Derviş ve Toplum (13-15. Yüzylllar). İstanbul: 2008.

Ayönü, Yusuf. Selçuklular ve Bizans, Ankara: 2014.

Azamat, Nihat. "Evhadüddîn-İ Kirmânı̂”. Türkiye Diyanet Vakfi İslâm Ansiklopedisi. 11/518-520. İstanbul: TDV Yayınları, 1995.

Bardakçı, Murat. "Türklerin Sosyal ve Kültürel Hayatında Tasavvuf ve Tarikatlerin Yeri”. Türkler. VII/450-461. Ankara: 2002.

Barkan, Ömer Lütfi. “İstila Devrinin Kolonizatör Türk Dervişleri”. Vakıflar Dergisi. II/179-304. Ankara: 1974.

Baskıcı, M. Murat. Bizans Döneminde Anadolu: Iktisadi ve Sosyal Yapı (900-1261). Ankara: 2009.

Bilgin, Orhan. "Fahreddîn-İ Irâkî”. Türkiye Diyanet Vakfi İslâm Ansiklopedisi. 12/84-86. İstanbul: TDV Yayınları, 1995.

Bréhier, Louis. The Life And Death Of Byzantium. çev. Margaret Vaughan. Amsterdam: 1977.

Charanis, Peter. The Byzantine Empire In The Eleventh Century, A History Of The Crusades. I. Madison: 1969.

Çapan, Fatma. Kösedă̆ Savaşına Giden Yolda Türkiye Selçuklu Devletinde İç Siyasi Durum. Sivas: 2018.

Demirci, Mehmet. "Müslüman Türklerde Tasavvuf”. Türkler. V/489-497. Ankara: 2002.

Demirkent, Işın. Haçlı Seferleri. İstanbul: 1997.

Demirli, Ekrem. İslam Metafiziğinde Tanrl ve İnsan: İbnü’l-Arabî ve Vahdet-i Vücûd Geleneği. İstanbul: 2009.

Demirli, Ekrem. "Vahdet-i Vücûd". Türkiye Diyanet Vakfi İslâm Ansiklopedisi. 42/431-435. İstanbul: TDV Yayınlar1, 2012.

Emecen, M. Feridun. İlk Osmanlılar ve Batı Anadolu Beylikler Dünyası. İstanbul: 2001.

Göksu, Erkan. Kösedă̆ Savaşı ve Türkiye Selçuklu Ordusu. Sivas: 2018.

Gölpınarlı, Abdülbaki. İslam ve Türk İllerinde Fütüvvet Teşkilatı. İstanbul: 2011.

Güzel, Abdurrahman. Kaygusuz Abdal. Ankara: 1981.

Hammer, Baron Joseph Van Purgstall. Büyük Osmanl Tarihi. I. İstanbul: 1989.

Harris, Jonathan. Byzantium And Crusades. New York: 2003.

Kafal1, Mustafa. “Anadolu'nun Fethi ve Türkleşmesi”. Türkler. VI/177-193. Ankara: 2002.

Kafesoğlu, İbrahim. Selçuklu Tarihi. İstanbul: 1992.

Kheil, Machiel. "Sarı Saltuk”. Türkiye Diyanet Vakfi İslâm Ansiklopedisi. 36/147-150. İstanbul: TDV Yayınları, 2009.

Komnena, Anna. Alexiad. çev. Bilge Umar. İstanbul: 1996.

Köprülü, M. Fuad. “Anadolu Selçuklu Tarihi’nin Yerli Kaynakları”. Belleten. VII (27)/379-522. Ankara: 1943.

Köprülü, M. Fuad. Türk Edebiyatında İlk Mutasavviflar. İstanbul: 1976.

Köprülü, M. Fuad. Osmanlı Devleti'nin Kuruluşu. Ankara: 1984. 
Köprülü, M. Fuad. Anadolu'da İslamiyet. Ankara: 2005.

Köprülü, Orhan F. "Abdal Kumral”, Türkiye Diyanet Vakfi İslâm Ansiklopedisi. I/63. İstanbul: TDV Yayınları, 1988.

Körülü, M. Fuad. "Anadolu Beylikleri Tarihine Ait Notlar”. Tarih Mecmuast. II/1-32. İstanbul: 1928.

Kurt, Yılmaz. "Ramazanoğulları Beyliği”. Türkler. VI/816-823. Ankara: 2002.

Kütük, Ahmet. Kösedă̆ Savaşının Kaybedilmesinde II. Gıyaseddin Keyhüsrev'in Kişiliği ve Uygulamalarının Rolü. Sivas: 2018.

Maalouf, Amin. Arapların Gözünden Haçlı Seferleri. çev. Ali Berktay. İstanbul: 2012.

Merçil, Erdoğan. Müslüman Türk Devletleri Tarihi. İstanbul: 1985.

Nur, Riza. Türk Tarihî. III. İstanbul: 1979.

Ocak, Ahmet Yaşar. "Baba İlyas”. Türkiye Diyanet Vakfi İslâm Ansiklopedisi. 4/368. İstanbul: TDV Yayınları, 1991.

Ocak, Ahmet Yaşar. XIII. Yüzyılda Anadolu'da Babaîler İsyanı. İstanbul: 1980.

Ocak, Ahmet Yaşar. Bektaşi Menakıbnâmelerinde İslâm Öncesi İnanç Motifleri. İstanbul: 1983.

Ocak, Ahmet Yaşar. "Barak Baba”. Türkiye Diyanet Vakfi İslâm Ansiklopedisi. 5/61-62, İstanbul: TDV Yayınları, 1992.

Ocak, Ahmet Yaşar. Osmanlı Imparatorluğunda Marjinal Sûfilik: Kalenderîler. Ankara: 1992.

Ocak, Ahmet Yaşar. "Geyikli Baba”. Türkiye Diyanet Vakfi İslâm Ansiklopedisi. 24/45-47. İstanbul: TDV Yayınları, 1996.

Ocak, Ahmet Yaşar. "Hacı Bektâş-I Velî”. Türkiye Diyanet Vakfi İslâm Ansiklopedisi. 14/455-458. İstanbul: TDV Yayınları, 1996.

Ocak, Ahmet Yaşar. "Selçuklu ve Beylikler Devrinde Düşünce”. Türkler. VII/431-432. Ankara : 2002.

Ocak, Ahmet Yaşar. Babâîler İsyânı ve Bektâş̧îlik. İstanbul: 2014.

Ocak, Ahmet Yaşar. Babailer İsyanı (Aleviliğin Tarihsel Altyapısı Yahut Anadolu'da İslam-Türk Heterodoksisinin Teșekkülü. Ankara : 2016

Oldenbourg, Zoé. The Crusades. New York: 1966.

Öcalan, Hasan Basri. “Anadolu Selçukluları Zamanında Tasavvufî Düșünce”. Türkler. VII/462-470. Ankara: 2002.

Öngören, Reşat. "Mevlânâ Celâleddîn-i Rûmî". Türkiye Diyanet Vakfi İslâm Ansiklopedisi. 29/441-448. İstanbul: TDV Yayınları, 2004.

Runciman, Steve. Haçlı Seferleri Tarihi I. Ankara: 1986.

Sarıkaya, M. Saffet. "Türklerin İslamlaşma Süresince Mezheplerin ve Tarikatların Yeri”, Türkler. V/498-508. Ankara: 2002.

Sevim, Ali. Anadolu'nun Fethi: Selçuklular Dönemi. Ankara: 1993.

Sevim, Ali-Merçil, Erdoğan. Selçuklu Devletleri Tarihi Siyaset, Teşkilat ve Kültür. Ankara: 2014.

Sevim, Ali - Yücel, Yaşar. Türkiye Tarihi: Fetihten Osmanlıya Kadar I. Ankara: 1995.

Sümer, Faruk. “Anadolu'da Moğollar”, Selçuklu Araştırmaları Dergisi, I (1969) /1-47.

Sümer, Faruk. "Ramazanoğulları”. Türkiye Diyanet Vakfi İslâm Ansiklopedisi. 24/442-447. İstanbul: TDV Yayınları, 2007.

Şahin, İlhan. "Ahî Evran”. Türkiye Diyanet Vakfi İslâm Ansiklopedisi. I/529-230. İstanbul: TDV Yayınları, 1988.

Taeschner, Franz. "İslâm Ortaçağında Futuvva (Fütüvvet Teşkilatı)". çev. Fikret Ișıltan. İstanbul Üniversitesi Illahiyat Fakültesi Mecmuası (IFM). XV/1-35. İstanbul: 1953.

Taşçı, Kemal. Kösedă̆ Savaşı Öncesi Moğolların Doğu Anadolu'daki Siyasi ve Askeri Faaliyetleri. 161-198. Sivas: 2018.

Tatc1, Mustafa. "Yunus Emre". Türkiye Diyanet Vakfi İslâm Ansiklopedisi. 43/600-606. İstanbul: TDV Yayınları, 2013.

Tosun, Necdet. "Yeseviyye”. Türkiye Diyanet Vakfi Íslâm Ansiklopedisi. 43/487-490. İstanbul: TDV Yayınları, 2013.

Tulum, Mertol. "Hikmetlere Göre Yesevîlik ve Orta Asya Kültür Tarihi Bakımından Önemi”. İlmî Araștırmalar. 7/207-221. İstanbul: 1999.

Turan, Osman. Selçuklular Zamanında Türkiye. İstanbul: 1971.

Turan, Osman. Selçuklular ve İslâmiyet. İstanbul: 1980.

Turan, Osman. Selçuklular Tarihi ve Türk İslâm Medeniyeti. İstanbul: 1993.

Uluçay, Çağatay. İlk Müslüman Türk Devletleri Tarihi. İstanbul: 1977.

Yıldız, Hakkı Dursun. Doğuştan Günümüze Büyük İslâm Tarihi, VII: Selçuklular. İstanbul: Çağ Yayınları: 1989.

Yinanç, Mükrimin Halil. “Anadolu'nun Fethi”. Türkler. VI/194-202. Ankara: 2002. 